\title{
Synthesis, characterization, thermodynamics and biological studies of binary and ternary complexes including some divalent metal ions, 2 , 3-dihydroxybenzoic acid and $\mathrm{N}$-acetylcysteine
}

\author{
Shella Permatasari Santoso ${ }^{a}$, Artik Elisa Angkawijaya ${ }^{b}, Y^{i-H s u ~ J u}{ }^{a, *}, F^{2}$ Felycia Edi Soetaredjo ${ }^{c}$, \\ Suryadi Ismadji ${ }^{\mathrm{c}}$, Aning Ayucitra ${ }^{\mathrm{C}}$
}

a Department of Chemical Engineering, National Taiwan University of Science and Technology, Taipei 10607, Taiwan

${ }^{\mathrm{b}}$ Institute of Plant and Microbial Biology, Academia Sinica, Taipei 11529, Taiwan

${ }^{c}$ Department of Chemical Engineering, Widya Mandala Surabaya Catholic University Kalijudan 37, Surabaya 60114, Indonesia

\section{A R T I C L E I N F O}

\section{Article history:}

Received 9 April 2016

Revised 1 July 2016

Accepted 1 August 2016

Available online 9 September 2016

\section{Keywords:}

2, 3-Dihydroxybenzoic acid

Acetylcysteine

Divalent metal

Complex synthesis

Metal-ligand

Thermodynamic

\begin{abstract}
A B S T R A C T
The binary complexes with the $[\mathrm{M}(\mathrm{Dhba})]^{-}$core and ternary complexes with $[\mathrm{M}(\mathrm{Dhba})(\mathrm{Nac})]^{3-}$ core have been synthesized and characterized by physical and spectral analyses, where $\mathrm{M}$ is divalent metal $\left(\mathrm{Mn}^{2+}\right.$, $\mathrm{Co}^{2+}, \mathrm{Ni}^{2+}, \mathrm{Cu}^{2+}$ or $\mathrm{Zn}^{2+}$ ) and Dhba and Nac are 2, 3-dihydroxybenzoic acid and $\mathrm{N}$-acetylcysteine, respectively. The synthesized complexes are practical in biological applications since they are soluble in water. The synthesized complexes were found to possess enhanced antimicrobial activity, especially against Staphylococcus aureus, but reduced DPPH scavenging activity of Dhba. The binary and ternary complexes of $\mathrm{Zn}^{2+}$ were shown to possess the most remarkable properties thus their structures were further examined. Thermodynamic properties of the $\mathrm{Zn}^{2+}$ complexes in aqueous solution at various temperatures were also determined with an ionic strength of $0.15 \mathrm{~mol} / \mathrm{dm}^{3} \mathrm{NaCl}$.
\end{abstract}

(C) 2016 Taiwan Institute of Chemical Engineers. Published by Elsevier B.V. All rights reserved.

\section{Introduction}

Synthesis of chelate complex drugs is one of the solutions to deal with pathogenic microbes which are becoming more and more drug resistance [1,2]. Bioactive organic ligands such as amino acids, phenolic acids and alkaloids coupled with essential metals are frequently employed in chelate complex synthesis [3-6]. 2, 3Dihydroxybenzoic acid (Dhba) is an effective phenolic compound not only with regard to its biological ability such as antioxidant, antibacterial and anti-inflammatory [7,8], but also to its ability to form stable chelate complexes with various metal ions [9-11]. Therefore, Dhba was chosen as the ligand for the synthesis of metal-ligand binary complexes in this study. Ternary chelate complexes involving mixed ligands (Dhba and $\mathrm{N}$-acetylcysteine (Nac)) were also synthesized. Nac was chosen as the consort ligand since it has been known to play an important role as a precursor of glutathione, an important antioxidant, and also known as potential

\footnotetext{
Corresponding author at: Department of Chemical Engineering, National Taiwan University of Science and Technology, \#43, Sec. 4, Keelung Road, Taipei 106-07, Taiwan. Fax: +886 227376644

E-mail address: yhju@mail.ntust.edu.tw (Y.-H. Ju).
}

sulfur replenishment for living organisms [12,13]. Moreover, Nac can form coordination compounds with metal ions [11,14,15].

In this study, binary and ternary complexes including Dhba, Nac and some divalent metal ions such as $\mathrm{Mn}^{2+}, \mathrm{Co}^{2+}, \mathrm{Ni}^{2+}, \mathrm{Cu}^{2+}$ and $\mathrm{Zn}^{2+}$ were synthesized and characterized. The chelate complexes were initially characterized by FTIR and UV-vis spectroscopy analyses. Scavenging activity and antibacterial activity of the complexes were examined. Subsequently, binary and ternary complexes with high biological activity were further studied using elemental analysis, ${ }^{1} \mathrm{H}$ NMR and thermogravimetric analysis; their thermodynamic properties were also determined.

\section{Experimental}

\subsection{Materials and instruments}

Copper chloride dihydrate $\left(\mathrm{CuCl}_{2} \cdot 2 \mathrm{H}_{2} \mathrm{O}, 99 \%\right.$ purity), cobalt nitrate hexahydrate $\left(\mathrm{Co}\left(\mathrm{NO}_{3}\right)_{2} \cdot 6 \mathrm{H}_{2} \mathrm{O}, 98 \%\right.$ purity), zinc nitrate hexahydrate $\left(\mathrm{Zn}\left(\mathrm{NO}_{3}\right)_{2} \cdot 6 \mathrm{H}_{2} \mathrm{O}, 98 \%\right.$ purity), Dhba $\left(\mathrm{C}_{7} \mathrm{H}_{6} \mathrm{O}_{4}\right.$, $99 \%$ purity) and $\mathrm{Nac}\left(\mathrm{C}_{5} \mathrm{H}_{9} \mathrm{NO}_{3} \mathrm{~S}, 99 \%\right.$ purity) were purchased from Sigma-Aldrich (St. Louis, MO); nickel chloride hexahydrate $\left(\mathrm{NiCl}_{2} \cdot 6 \mathrm{H}_{2} \mathrm{O}, 98 \%\right.$ purity) was obtained from Alfa Aesar (Lancashire, UK); manganese chloride tetrahydrate $\left(\mathrm{MnCl}_{2} \cdot 4 \mathrm{H}_{2} \mathrm{O}\right.$, 99.8\% purity) was supplied by Fisher Scientific (Bridgewater, NJ). 
Sodium hydroxide $(\mathrm{NaOH}, 96 \%$ purity) was supplied by Yakuri Chemical (Kyoto, Japan). Ethanol $\left(\mathrm{C}_{2} \mathrm{H}_{6} \mathrm{O}, 95 \%\right.$ purity) was provided by Echo Chemical (Miaoli, Taiwan). All chemicals were analytical grade and were used without further purification.

$\mathrm{N}, \mathrm{C}, \mathrm{S}$ and $\mathrm{H}$ analysis was performed using an Elementar Vario EL Cube analyzer (Hanau, Germany). Metal contents (Mn, Co, Ni, $\mathrm{Cu}, \mathrm{Zn}$ and $\mathrm{Na}$ ) of the complexes were determined by an ICP-AES JY 2000-2. The commercial ICP metal standard solution (1000 mg/l of metal in $0.5 \mathrm{~mol} / \mathrm{l} \mathrm{HNO}_{3}$ ) was used as the calibrant. Chloride content was determined by using an ion chromatograph Dionex ICS-1000. FTIR spectra were recorded with a Bio-Rad FTS-3500 on $\mathrm{KBr}$ disc with spectra range of $400-4000 \mathrm{~cm}^{-1}$. UV-vis spectra of the complexes in $\mathrm{H}_{2} \mathrm{O}$ solvent were measured in the wavelength range of $200-500 \mathrm{~nm}$ by using a Jasco V-550 spectrophotometer. Conductivities of the complexes in water were measured using a Knick Konduktometer 703. Magnetic susceptibilities of powder samples at $300 \mathrm{~K}$ were measured using a MPMS7 Quantum Design SQUID Magnetometer. ${ }^{1} \mathrm{H}$ NMR spectra were measured on a Bruker AVIII-600 MHz FT-NMR in $\mathrm{D}_{2} \mathrm{O}$ solution. Thermogravimetric analyses in the range of 30 to $900^{\circ} \mathrm{C}$ were examined by using a Perkin Elmer Diamond TG/DTA. Thermodynamic properties in $0.15 \mathrm{~mol} / \mathrm{dm}^{3} \mathrm{NaCl}$ ionic medium at various temperatures were measured potentiometrically under $\mathrm{N}_{2}$ atmosphere by using a Metrohm 888 Titrando potentiometer with Ecotrode Plus pH glass electrode.

\subsection{Synthesis of binary and ternary complexes}

Binary complexes were synthesized by dissolving Dhba $(0.16 \mathrm{~g}$, $1 \mathrm{mmol}$ ) in $14 \mathrm{ml} \mathrm{H}_{2} \mathrm{O}$ with the addition of $1 \mathrm{ml} \mathrm{95 \%} \mathrm{ethanol.} \mathrm{The}$ ligand was allowed to dissolve by slowly adding a few drops of $\pm 5 \mathrm{M} \mathrm{NaOH}$ solution until $\mathrm{pH} 11.0$ was reached, $\mathrm{NaOH}$ solution was directly used without standardization. Five milliliters of $1 \mathrm{mmol}$ metal salt solution $\left(0.17 \mathrm{~g} \mathrm{CuCl} 2 \cdot 2 \mathrm{H}_{2} \mathrm{O} ; 0.30 \mathrm{~g} \mathrm{Zn}\left(\mathrm{NO}_{3}\right)_{2} \cdot 6 \mathrm{H}_{2} \mathrm{O}\right.$; $0.24 \mathrm{~g} \mathrm{NiCl}_{2} \cdot 6 \mathrm{H}_{2} \mathrm{O}$; $0.30 \mathrm{~g} \mathrm{Co}\left(\mathrm{NO}_{3}\right)_{2} \cdot 6 \mathrm{H}_{2} \mathrm{O}$; or $0.20 \mathrm{~g} \mathrm{MnCl}_{2} \cdot 4 \mathrm{H}_{2} \mathrm{O}$ ) was added into the solution. The $\mathrm{pH}$ again was adjusted to 11.0 by using $\pm 5 \mathrm{M} \mathrm{NaOH}$. The mixture was allowed to react for $6 \mathrm{~h}$ with constant stirring. Any solid in the solution was removed by filtration. The solution was freezed in $-40{ }^{\circ} \mathrm{C}$ and then subjected to lyophilization. The dried complex was washed with ethanol and dried in a $50^{\circ} \mathrm{C}$ oven for $4 \mathrm{~h}$, then stored in a desiccator.

Ternary complexes were synthesized similarly to that of binary complexes with the addition of Nac $(0.16 \mathrm{~g}, 1 \mathrm{mmol})$.

\subsection{Scavenging activity}

Scavenging activity of complexes was tested against the stable radical 2,2-diphenyl-1-picrylhydrazyl (DPPH) [16]. The tested complex was prepared at concentrations of 1 and $2 \mu \mathrm{g} / \mathrm{ml}$. The complex was firstly dissolved in water, then methanol was added at a water to methanol ratio of $1: 19(\mathrm{v} / \mathrm{v})$. DPPH solution was prepared at a concentration of $5 \times 10^{-4} \mathrm{~mol} / \mathrm{l}$ in aqueous solution with the same water to methanol ratio. DPPH solution $(0.2 \mathrm{ml})$ was added to the prepared complex $(0.8 \mathrm{ml})$. The tested complexes incubated at $37^{\circ} \mathrm{C}$ for $30 \mathrm{~min}$ and its absorbance was measured at $517 \mathrm{~nm}$ against methanol blank. DPPH $(0.2 \mathrm{ml})$ in methanol $(0.8 \mathrm{ml})$ was used as the control. Percent DPPH inhibition was calculated as:

$\% \mathrm{DPPH}$ inhibition $=\left(\left[A_{\mathrm{c}}-A_{\mathrm{S}}\right] / A_{\mathrm{C}}\right) \times 100$

where $A_{\mathrm{c}}$ and $A_{\mathrm{s}}$ are the absorbance of control and the absorbance of sample, respectively. Ascorbic acid was used as the positive controls.

\subsection{Antimicrobial activity}

The antimicrobial potency of the complexes was tested against gram positive Staphylococcus aureus and gram negative Escherichia coli. Broth macrodilution method was used for the inhibitory activity determination [17]. Ampicilin ( $895.5 \mu \mathrm{g} / \mathrm{ml}$ potency) was used as the reference. The complex was prepared at four concentrations $(100,600,1000$ and $2000 \mu \mathrm{g} / \mathrm{ml})$. The assay was performed in test tubes each containing the tested compound dissolved in Lysogeny Broth media. Fifteen microliters of the prepared bacteria suspension $\left(1 \times 10^{8} \mathrm{cfu} / \mathrm{ml}\right)$ were injected into each tube. After incubated for $24 \mathrm{~h}$ at $37^{\circ} \mathrm{C}$, optical density at $600 \mathrm{~nm}$ wavelength $\left(\mathrm{OD}_{600 \mathrm{~nm}}\right)$ of each sample was measured. As the growth control, $15 \mu \mathrm{l}$ of bacteria suspension was injected into test tube containing no sample. The antimicrobial activity is expressed as \%inhibition, calculated as:

$\%$ inhibition $=\left(\left[I_{\mathrm{C}}-I_{\mathrm{S}}\right] / I_{\mathrm{C}}\right) \times 100$

where $I_{\mathrm{C}}$ is the absorbance of control and $I_{\mathrm{S}}$ is the absorbance of sample.

\subsection{Thermodynamic properties}

Thermodynamic properties were determined potentiometrically by titrating $50 \mathrm{~cm}^{-3}$ mixture of metal salts $\left(0.001 \mathrm{~mol} / \mathrm{dm}^{3}\right)$ and $0.001-0.003 \mathrm{~mol} / \mathrm{dm}^{3}$ of Dhba and/or Nac. The mixture was acidified to $\mathrm{pH} 2.5$ by adding $0.003 \mathrm{~mol} / \mathrm{dm}^{3} \mathrm{HCl}$. The ionic strength maintained by adding $0.15 \mathrm{~mol} / \mathrm{dm}^{3} \mathrm{NaCl}$. The mixture was titrated by $0.1 \mathrm{~mol} / \mathrm{dm}^{3}$ carbonate free- $\mathrm{NaOH}$ under $\mathrm{N}_{2}$ atmosphere until pH 11.0 was reached. Stability constant of binary complex was determined at metal to ligand ratios of $1: 1,1: 2$ and $1: 3$ while ternary complex was determined from metal to ligand ratio of $1: 1: 1$. Stability constants were determined at 25,45 and $55^{\circ} \mathrm{C}$. Analyses of the titration data were done by using Hyperquad2008 [18].

\section{Results and discussion}

Metal-ligand complexes with deprotonated species as core (specifically $[\mathrm{M}(\mathrm{Dhba})]^{-}$and $[\mathrm{M}(\mathrm{Dhba})(\mathrm{Nac})]^{3-}$, for binary and ternary species respectively) were synthesized at $\mathrm{pH}$ 11.0. This $\mathrm{pH}$ was chosen for the synthesis reaction since at this $\mathrm{pH}$ value core species were found to exist in the highest concentration, as shown in the distribution diagram in Supplementary Data Fig. S1 for $\mathrm{Zn}^{2+}$ systems. The synthesized complexes were then characterized by FTIR and UV-vis spectra analyses. DPPH scavenging and antimicrobial activities of complexes were evaluated. The results of elemental analysis, conductivity and magnetic measurements of $\mathrm{Zn}^{2+}$ binary and ternary complexes are presented in this section while the results of other metal ions complexes are summarized in the supplementary data (Table S1).

\subsection{FTIR spectra}

\subsubsection{Binary complexes}

The characteristic main bands in IR spectra of the ligands and binary complexes are listed in Table 1, while the IR spectra are presented in the supplementary data (Figs. S2 and S3). In the absence of metal ions, Dhba possessed bands at $3240 \mathrm{~cm}^{-1}$ and 3048 $\mathrm{cm}^{-1}$ corresponding to $v(\mathrm{OH})$ of hydroxyl and carboxyl group, respectively. The IR spectrum of the free Dhba reveals a band at 1680 $\mathrm{cm}^{-1}$ due to $v(\mathrm{C}=\mathrm{O})$ and $v(\mathrm{C}-\mathrm{OH})$ of protonated carboxyl group, respectively. The band at $1566 \mathrm{~cm}^{-1}$ is attributed to the $v(\mathrm{C}=\mathrm{C})$ of Dhba aromatic ring, in the complexes this band is found at 1530$1548 \mathrm{~cm}^{-1}$. Several new bands can be found in the metal complex system. The first is the $v(\mathrm{OH})$ band at $3478-3471 \mathrm{~cm}^{-1}$ and $837-$ $811 \mathrm{~cm}^{-1}$ regions are due to coordinated water molecule [6,19]. Two new bands at $1618-1617 \mathrm{~cm}^{-1}$ and $1473-1431 \mathrm{~cm}^{-1}$ are contributed to $v\left(\mathrm{COO}^{-}\right)$asy and $v\left(\mathrm{COO}^{-}\right)_{\text {sym }}$ of deprotonated carboxylic group, $\Delta v$ of $145-187 \mathrm{~cm}^{-1}$ suggests that this group is unbounded. 
Table 1

Selected IR spectra for the synthesized binary and ternary complexes.

\begin{tabular}{|c|c|c|c|c|c|c|c|c|c|c|c|c|c|c|c|c|}
\hline \multirow[t]{3}{*}{ Complex } & \multicolumn{16}{|c|}{ IR spectra $\left(\mathrm{cm}^{-1}\right)$} \\
\hline & \multicolumn{7}{|l|}{ Binary } & \multicolumn{9}{|c|}{ Ternary } \\
\hline & $v(\mathrm{OH})$ & $v(\mathrm{C}=0)$ & $v\left(\mathrm{COO}^{-}\right)$ & $v(\mathrm{C}=\mathrm{C})$ & $v(\mathrm{C}-\mathrm{OH})$ & $v(\mathrm{MO})$ & other & $v(\mathrm{NH})$ & $v(\mathrm{OH})$ & $v(\mathrm{SH})$ & $v(\mathrm{C}=\mathrm{O})$ & $v\left(\mathrm{COO}^{-}\right)$ & $v(\mathrm{C}=\mathrm{C})$ & $v(\mathrm{C}-\mathrm{OH})$ & $v(\mathrm{MO})$ & Other \\
\hline \multicolumn{17}{|l|}{ Ligand } \\
\hline Dhba & $\begin{array}{l}3240 \\
3048\end{array}$ & 1680 & - & 1566 & 1259 & - & - & - & $\begin{array}{l}3240 \\
3048\end{array}$ & - & 1680 & - & 1566 & 1259 & - & - \\
\hline $\mathrm{Nac}$ & - & - & - & - & - & - & - & $\begin{array}{l}3376 \\
796\end{array}$ & 2810 & 2548 & 1718 & - & - & 1229 & - & - \\
\hline \multicolumn{17}{|l|}{ Complex of } \\
\hline Copper & $\begin{array}{l}3478 \\
811\end{array}$ & - & $\begin{array}{l}1618 \\
1451\end{array}$ & 1548 & 1216 & 477 & 620 & 755 & $\begin{array}{l}3449 \\
806\end{array}$ & - & - & $\begin{array}{l}1548 \\
1440\end{array}$ & 1548 & 1217 & 516 & 588 \\
\hline Zinc & $\begin{array}{l}3471 \\
820\end{array}$ & - & $\begin{array}{l}1618 \\
1445\end{array}$ & 1537 & 1192 & 476 & $\begin{array}{l}1384 \\
1222\end{array}$ & 746 & $\begin{array}{l}3385 \\
810\end{array}$ & - & - & $\begin{array}{l}1627 \\
1501\end{array}$ & 1573 & 1214 & 457 & $\begin{array}{l}1384 \\
1254\end{array}$ \\
\hline Nickel & $\begin{array}{l}3477 \\
837\end{array}$ & - & $\begin{array}{l}1617 \\
1445\end{array}$ & 1533 & 1196 & 476 & 621 & 745 & $\begin{array}{l}3373 \\
834\end{array}$ & - & - & $\begin{array}{l}1628 \\
1502\end{array}$ & 1565 & 1228 & 458 & 599 \\
\hline Cobalt & $\begin{array}{l}3478 \\
834\end{array}$ & - & $\begin{array}{l}1618 \\
1473\end{array}$ & 1530 & 1191 & 476 & $\begin{array}{l}1384 \\
1251\end{array}$ & 758 & $\begin{array}{l}3352 \\
826\end{array}$ & - & - & $\begin{array}{l}1615 \\
1471\end{array}$ & 1580 & 1218 & 457 & $\begin{array}{l}1384 \\
1258\end{array}$ \\
\hline Manganese & $\begin{array}{l}3478 \\
813\end{array}$ & - & $\begin{array}{l}1618 \\
1431\end{array}$ & 1530 & 1218 & 478 & 621 & 746 & $\begin{array}{l}3371 \\
813\end{array}$ & - & - & $\begin{array}{l}1659 \\
1492\end{array}$ & 1566 & 1220 & 457 & 597 \\
\hline
\end{tabular}

The $v(\mathrm{C}-\mathrm{OH})$ band at $1191-1218 \mathrm{~cm}^{-1}$ is due to ethanol. The complex of $\mathrm{Cu}^{2+}, \mathrm{Ni}^{2+}$ and $\mathrm{Mn}^{2+}$ possessed band at $621-620 \mathrm{~cm}^{-1}$ indicating the ionic $\mathrm{Cl}^{-}$; while for $\mathrm{Zn}^{2+}$ and $\mathrm{Co}^{2+}$ the bands at 1384 and $1251-1222 \mathrm{~cm}^{-1}$ indicate the coordinated $\mathrm{NO}_{3}{ }^{-}$in monodentate mode [20]. The ionic groups of $\mathrm{Cl}^{-}$and $\mathrm{NO}_{3}{ }^{-}$were originated from the type of metal salts used. The new band appeared at 477, $476,476,476$ and $478 \mathrm{~cm}^{-1}$ are attributed to $v(\mathrm{MO})$ for $\mathrm{Cu}^{2+}, \mathrm{Zn}^{2+}$, $\mathrm{Ni}^{2+}, \mathrm{Co}^{2+}$ and $\mathrm{Mn}^{2+}$, respectively.

\subsubsection{Ternary complexes}

The IR absorption bands of the ternary complexes are listed in Table 1 as well as binary complexes (the full spectra are presented in supplementary data Fig. S4). The ligand Nac $v(\mathrm{NH})$ stretching and bending vibration was observed at 3376 and $796 \mathrm{~cm}^{-1}$, respectively. The stretch of $v(\mathrm{OH}), v(\mathrm{C}=\mathrm{O})$ and $v(\mathrm{CO})$ bond from protonated carboxylate group produced band at $2810 \mathrm{~cm}^{-1}, 1718 \mathrm{~cm}^{-1}$ and $1229 \mathrm{~cm}^{-1}$ respectively. The thiol $v(\mathrm{SH})$ frequency of Nac was characterized at $2548 \mathrm{~cm}^{-1}$, while in the complex this band disappeared, evidencing that this group was involved in chelation after deprotonation. The synthesized ternary complexes inherited the main spectra from both Dhba and Nac. The $v(\mathrm{OH})$ at 3449-3352 $\mathrm{cm}^{-1}$ and band at $834-806 \mathrm{~cm}^{-1}$ in all metal systems indicate the coordinated water molecule [6,19]. The bending of $v(\mathrm{NH})$ at $758-$ $745 \mathrm{~cm}^{-1}$ was still visible in the complexes, while the stretching of $v(\mathrm{NH})$ at higher region cannot be observed since the band is probably stacked with the $v(\mathrm{OH})$ band. Two bands at 1659$1548 \mathrm{~cm}^{-1}$ and $1502-1440 \mathrm{~cm}^{-1}$ are contributed to $v\left(\mathrm{COO}^{-}\right)$asy and $v\left(\mathrm{COO}^{-}\right)_{\text {sym }}$ of the deprotonated carboxylic group, $\Delta v=108^{-}$ $167 \mathrm{~cm}^{-1}$ indicating the monodentate binding of the carboxylic group [6,19]. The $v(\mathrm{C}-\mathrm{OH})$ band at $1214-1228 \mathrm{~cm}^{-1}$ is due to ethanol. The ionic group $\mathrm{Cl}^{-}$originated from metal salts appeared at $599-588 \mathrm{~cm}^{-1}$ for $\mathrm{Cu}^{2+}, \mathrm{Ni}^{2+}$ and $\mathrm{Mn}^{2+}$, while coordinated $\mathrm{NO}_{3}{ }^{-}$in monodentated mode appeared at 1384 and 1258-1254 $\mathrm{cm}^{-1}$ for $\mathrm{Zn}^{2+}$ and $\mathrm{Co}^{2+}[20]$. The band which characterized the bond of ligand to metal, $v(\mathrm{MO})$ was observed at 516, 457, 458, 457 and $457 \mathrm{~cm}^{-1}$ for $\mathrm{Cu}^{2+}, \mathrm{Zn}^{2+}, \mathrm{Ni}^{2+}, \mathrm{Co}^{2+}$ and $\mathrm{Mn}^{2+}$, respectively.

\subsection{UV-vis spectra, conductivity and magnetic properties}

Absorption spectra of the synthesized binary and ternary complexes are shown in Fig. 1. The complexes show two absorption bands at $214-230 \mathrm{~nm}$ and $314-360 \mathrm{~nm}$ which correspond to $\pi-\pi^{*}$ and $n-\pi^{*}$ bonding of the benzene ring [21]. In binary and ternary cobalt complexes, $\mathrm{n}-\pi^{*}$ bonding was observed at longer wavelength (370-395 nm), while for manganese complexes the absorbance of this bonding was low and cannot be observed. The absorption bands for d-orbital of the metals cannot be observed since usually these spectra have low absorbance. In particular for ternary complex of $\mathrm{Co}^{2+}$, the spectrum corresponding to dorbital is observed at $499 \mathrm{~nm}$ which is attributed to the transition ${ }^{4} \mathrm{~A}_{2 \mathrm{~g}}(\mathrm{~F}) \rightarrow{ }^{4} \mathrm{~T}_{1 \mathrm{~g}}(\mathrm{P})$, indicating its octahedral geometry [22].

Magnetic susceptibilities $\left(\mu_{\text {eff }}\right)$ of the binary and ternary complexes were measured at $300 \mathrm{~K}$ and are summarized in Table S1. Low $\mu_{\text {eff }}$ values $(0.69-1.00 \mathrm{BM}$ for binary and $0.62-1.75 \mathrm{BM}$ for ternary complexes) suggest that the complexes only have one unpaired electron, and the complexes exhibit weak paramagnetic behavior. In $\mathrm{Zn}^{2+}$ binary and ternary complexes, the results of $\mu_{\mathrm{eff}}$ indicate diamagnetic behavior of the complexes. Meanwhile, $\mathrm{Co}^{2+}$ ternary complex exhibits higher $\mu_{\text {eff }}(2.38 \mathrm{BM})$ than other ternary metal complexes, this value is often observed for $\mathrm{Co}^{2+}$ complex with octahedral geometry and is also supported by the occurrence of the band at $499 \mathrm{~nm}$ in UV-vis spectra.

The molar conductivity $\left(\Lambda_{M}\right)$ measurements gave values of 153-179 $\mathrm{S} \mathrm{cm} \mathrm{cm}^{2} / \mathrm{mol}$ for binary complexes, while for ternary complexes the values were $217-242 \mathrm{~S} \mathrm{~cm} / \mathrm{mol}$ (Table $\mathrm{S} 1$ ). $\Lambda_{\mathrm{M}}$ of a complex indicates the electrolyte nature of the complex. The electrolyte behavior of a complex might be due to the presence of $\mathrm{Na}^{+}$ ions which were involved in the formation of the complex. Higher $\Lambda_{\mathrm{M}}$ of a ternary complex is because it contains more $\mathrm{Na}^{+}$ions than a binary complex.

\subsection{Biological activities}

\subsubsection{DPPH scavenging activity}

Scavenging activity of the complexes at concentrations of 1 and $2 \mathrm{mg} / \mathrm{l}$ were evaluated against DPPH. The tests in scavenging activity were done in triplicate. The results are summarized as the average value, and the difference between the three tests was indicated by the error bars, as shown in Fig. 2. The synthesized binary and ternary complexes did not show any increase in DPPH inhibition compared to Dhba. The possible reason is that originally Dhba inhibits DPPH by transferring $\mathrm{H}$ atom from $-\mathrm{COO}$ and meta $-\mathrm{O}$ group [23] while Nac inhibits DPPH by transferring $\mathrm{H}$ atom from -COO group [24]; in the formed complex $\mathrm{H}$ atoms of ligand which were originally inhibiting free radical formation disappeared thus inhibition activity actually decreased.

Ternary complexes have higher inhibition activity than binary complexes. The enhancement in activity is due to the addition of 

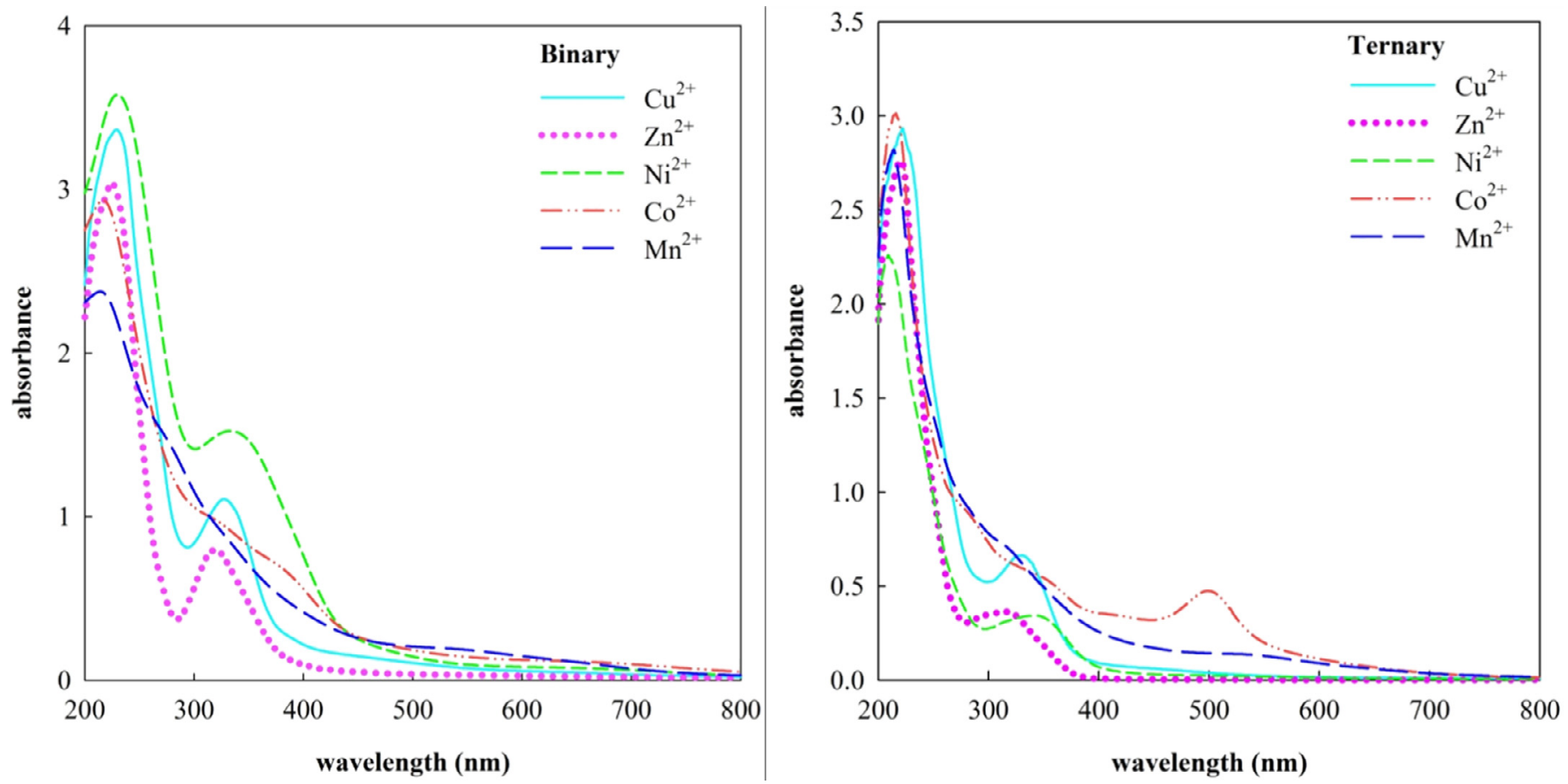

Fig. 1. Spectra of the binary and ternary complexes at concentration of $187.5 \mathrm{mg} / \mathrm{l}$.

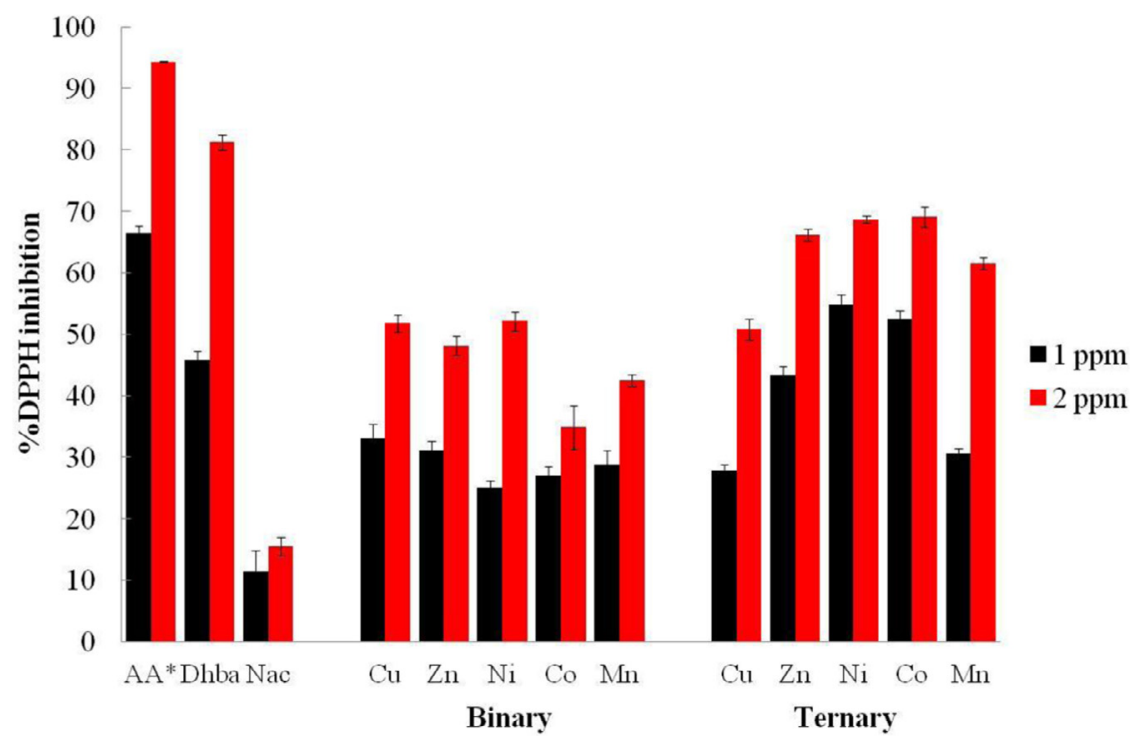

Fig. 2. DPPH scavenging activity of the complexes, *AA-ascorbic acid as the standard reference.

Nac, where amine group of Nac also contributes to bonding with DPPH through weak hydrogen bond. However for ternary complex of $\mathrm{Cu}^{2+}$, the inhibition activity is lower than that of binary $\mathrm{Cu}^{2+}$ perhaps due to the reaction of $\mathrm{Nac}$ and $\mathrm{Cu}^{2+}$ which is known to produce free radical [25].

\subsubsection{Antimicrobial activity}

Antimicrobial activities of the synthesized complexes were evaluated against $E$. coli and $S$. aureus. The inhibition values are reported as Supplementary Data (Tables S2-S4). Dhba was shown to have better antimicrobial activity than Nac. For the synthesized complexes, some exhibited lower antimicrobial activity than that of Dhba. The complexes were found to be more effective in inhibiting S. aureus. It was found that in binary and ternary complexes, the complex of $\mathrm{Zn}$ possessed the highest inhibition activity against the growth of bacteria. Thus it is worthwhile to diagnose the efficacy of zinc complexes by determining the minimum inhibitory concentration (MIC) as shown in Table 2. The complexes of zinc gave higher inhibition activity than ligand alone (especially against S. aureus) as indicated by the smaller MIC values.

The increase in bacterial growth inhibition of zinc complexes is perhaps due to the increase in solubility of the complexes. The solubility of Dhba in water is very low and becomes highly soluble in the form of chelate complex. The complexes were also found to be more effective to inhibit the growth of gram positive bacteria than gram negative bacteria. This is possibly due to difference in their cell walls [26,27]. As gram positive bacteria, S. aureus cell wall consists of thick peptidoglycan layer and plasma membrane while gram negative bacteria $E$. coli cell wall possesses an extra outer membrane layer which is high in lipid [28]. This lipid 
<smiles>[2H]c1c([15NH])c(O)c(O)c(C(=O)O)c1[TlH]</smiles><smiles>[CH][C@H](S)C(=O)N[14CH3]</smiles>

Fig. 3. Structure of ligand Dhba (left) and Nac (right).

Table 2

$\mathrm{MIC}^{\mathrm{a}}(\mu \mathrm{g} / \mathrm{ml})$ of the tested compounds.

\begin{tabular}{llllll}
\hline \multirow{2}{*}{ Compound } & \multicolumn{2}{l}{ E. coli } & & & \multicolumn{2}{l}{ S. aureus } \\
\cline { 2 - 3 } \cline { 5 - 6 } & $\mathrm{MIC}_{50}$ & $\mathrm{MIC}_{90}$ & & $\mathrm{MIC}_{50}$ & $\mathrm{MIC}_{90}$ \\
\hline Ampicilin & 4.1 & 49.1 & & 0.3 & 2.6 \\
Dhba & 589.8 & 1085.7 & 702.0 & 932.6 \\
Nac & 1293.9 & $>2000$ & $>2000$ & $>2000$ \\
Binary zinc & 603.5 & 867.0 & & 149.3 & 383.8 \\
Ternary zinc & 773.9 & 971.6 & & 347.1 & 554.8 \\
\hline
\end{tabular}

$\mathrm{MIC}_{50}$ and $\mathrm{MIC}_{90}$ are the minimum concentration requirement to inhibit 50\% and $90 \%$ growth of microorganism, respectively.

containing layer lowers the permeability of the complex into the bacteria inner membrane and cause decrease in inhibition activity.

\subsection{Complexes of zinc}

Since the complexes of $\mathrm{Zn}$ show higher biological activity than other metal complexes, only $\mathrm{Zn}$ complexes were chosen for further characterization including elemental analysis, ${ }^{1} \mathrm{H}$ NMR spectra, and thermogravimetric analysis.

\subsubsection{Binary complex of zinc}

The binary complex of $\mathrm{Zn}$ has the chemical formula $\mathrm{C}_{9} \mathrm{H}_{11} \mathrm{NNa}_{2}$ $\mathrm{O}_{9} \mathrm{Zn}$ or $\mathrm{Na}_{2}\left[\mathrm{Zn}\left(\mathrm{NO}_{3}\right)\left(\mathrm{C}_{7} \mathrm{H}_{3} \mathrm{O}_{4}\right)\left(\mathrm{H}_{2} \mathrm{O}\right)\right] \cdot \mathrm{C}_{2} \mathrm{H}_{6} \mathrm{O}, \quad m w=388.54$. It is dark green-brown in color. Elemental analysis on the complex indicated its composition as follows: C, 27.89; H, 2.84; N, 3.69; Na, $11.80 ; \mathrm{Zn}, 16.52 \%$ while the calculated (theoretical) composition is: C, 27.82; $\mathrm{H}, 2.85$; N, 3.61; Na, 11.83; Zn, $16.83 \%$. The ${ }^{1} \mathrm{H}$ NMR signals of Dhba (Fig. 3) were found at $\delta_{\mathrm{H}} 7.47(\mathrm{~d}, 1 \mathrm{H}, \mathrm{H}-1, J=6.5 \mathrm{~Hz}$ ), $7.16(\mathrm{~d}, 1 \mathrm{H}, \mathrm{H}-2, J=6.4 \mathrm{~Hz}), 6.88(\mathrm{t}, 1 \mathrm{H}, \mathrm{H}-3, J=8.0)$. The binary complex signals were shifted to lower values specifically $\delta_{\mathrm{H}} 7.12(\mathrm{~s}$, $1 \mathrm{H}, \mathrm{H}-1), 6.82(\mathrm{~s}, 1 \mathrm{H}, \mathrm{H}-2), 6.61(\mathrm{~s}, 1 \mathrm{H}, \mathrm{H}-3)$, followed by new signals at $\delta_{\mathrm{H}} 3.69\left(\mathrm{q}, 2 \mathrm{H}, \mathrm{CH}_{2}, J=7.1 \mathrm{~Hz}\right), 1.22\left(\mathrm{t}, 3 \mathrm{H}, \mathrm{CH}_{3}, J=7.1 \mathrm{~Hz}\right)$. The ${ }^{1} \mathrm{H}$ NMR signals are presented in Table 3 , while the spectrums are presented in Figs. S5 and S6. The new ${ }^{1} \mathrm{H}$ NMR signals in the complex were observed which corresponds to ethanol molecule. The attachment of ethanol molecule may also cause the shift in $v(\mathrm{OH})$ IR spectra at $3471 \mathrm{~cm}^{-1}$.

As indicated in the elemental analysis, $\mathrm{Na}^{+}$molecules were involved in the formation of complex. $\mathrm{Na}^{+}$molecules seem to help neutralizing the charge of the complex, which originally has a negative charge of 2 , thus isolation of the complex in solid phase is possible. Result of elemental analysis suggests that there was one $\mathrm{N}$ atom corresponding to $\mathrm{NO}_{3}$ involved in complex formation. Thus the proposed structure of zinc binary complex is shown in Fig. 4.

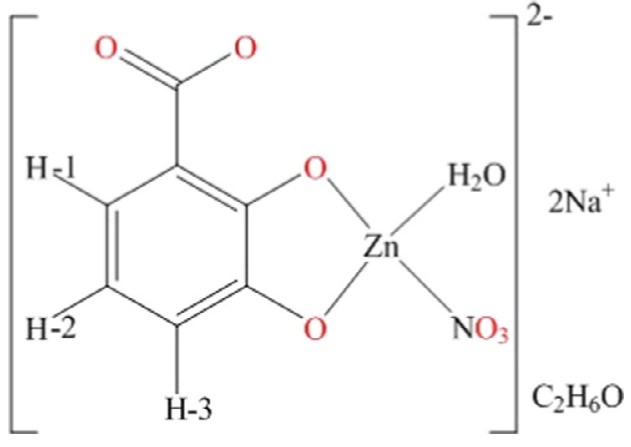

Fig. 4. Proposed structure of zinc binary complex.

\subsubsection{Ternary complex of zinc}

Ternary complex was found with chemical formula $\mathrm{C}_{14} \mathrm{H}_{18} \mathrm{~N}_{2}$ $\mathrm{Na}_{4} \mathrm{O}_{12} \mathrm{SZn}$ or $\mathrm{Na}_{4}\left[\mathrm{Zn}\left(\mathrm{NO}_{3}\right)\left(\mathrm{C}_{7} \mathrm{H}_{3} \mathrm{O}_{4}\right)\left(\mathrm{C}_{5} \mathrm{H}_{7} \mathrm{NO}_{3} \mathrm{~S}\right)\left(\mathrm{H}_{2} \mathrm{O}\right)\right] \cdot \mathrm{C}_{2} \mathrm{H}_{6} \mathrm{O}$, $m w=595.70$. The complex has a dark pale-brown color. Elemental analysis found the composition as: C, 28.46; H, 3.06; N, 4.72; S, 5.22; $\mathrm{Na}, 15.31 ; \mathrm{Zn}, 11.01 \%$ while the calculated (theoretical) one is: C, 28.23; $\mathrm{H}, 3.05 ; \mathrm{N}, 4.70 ; \mathrm{S}, 5.38$; Na, $15.44 ; \mathrm{Zn}, 10.98 \%$. More complicated ${ }^{1} \mathrm{H}$ NMR signals were observed in ternary complex. ${ }^{1} \mathrm{H}$ NMR signals for Dhba were the same as those in the binary complex, while for Nac (Fig. 3) the signals observed are $\delta_{\mathrm{H}} 4.66$ (q, $1 \mathrm{H}, \mathrm{CH}, J=4.9 \mathrm{~Hz}$ ), $3.02\left(\mathrm{sep}, 2 \mathrm{H}, \mathrm{CH}_{2}, J=9.4 \mathrm{~Hz}\right), 2.11(\mathrm{~s}, 3 \mathrm{H}$, $\left.\mathrm{CH}_{3}\right) .{ }^{1} \mathrm{H}$ NMR signals for zinc ternary complex (Table 5) are $\delta_{\mathrm{H}}$ 7.12-7.03 (m, 1H, H-1), 6.78 (br, 1H, H-2), 6.69-6.59 (m, 1H, H-3), 4.53 (q, $1 \mathrm{H}, \mathrm{CH} \mathrm{Nac}, J=4.1 \mathrm{~Hz}$ ), 3.69 (q, 2H, CH ethanol, $J=7.1 \mathrm{~Hz}$ ), 3.02-2.99 (dd, $2 \mathrm{H}, \mathrm{CH}_{2} \mathrm{Nac}, J=8.9 \mathrm{~Hz}$ ), 1.60 (s, 3H, $\mathrm{CH}_{3} \mathrm{Nac}$ ), 1.22 (t, $3 \mathrm{H}, \mathrm{CH}_{3}$ ethanol, $J=7.1 \mathrm{~Hz}$ ). The ${ }^{1} \mathrm{H}$ NMR spectrums of Nac and ternary complex are presented in Figs. S5 and S6.

Similarly in $\mathrm{Zn}$ ternary complex, $\mathrm{Na}^{+}$molecules also helped neutralizing the charge of the complex, which originally has a negative charge of 4 . Elemental analysis result also suggests the involvement of $\mathrm{NO}_{3}$ in complex formation. Thus the structure of zinc ternary complex can be proposed as shown in Fig. 5 .

\subsubsection{Thermogravimetric analyses}

Thermogravimetric analyses of $\mathrm{Zn}$ complexes were conducted in the temperature range of $30-900{ }^{\circ} \mathrm{C}$. The thermograms are provided in Supplementary Data (Figs. S5). In Zn binary complex, the initial mass loss which is observed until $200^{\circ} \mathrm{C}$ corresponds to loss of water and ethanol. Big mass loss at $280-340^{\circ} \mathrm{C}$ corresponds to the decomposition of Dhba, thus residue at above $450^{\circ} \mathrm{C}$ corresponds to zinc-oxide. For $\mathrm{Zn}$ ternary complex, the initial mass loss which was observed until $140^{\circ} \mathrm{C}$ corresponds to loss of water and ethanol. Mass loss at $145-550^{\circ} \mathrm{C}$ corresponds to the decomposition of ligand Nac along with Dhba and zinc-oxide residue was left at temperatures above $550^{\circ} \mathrm{C}$. 
Table 3

Selected ${ }^{1} \mathrm{H}$ NMR data of zinc binary and ternary complex.

\begin{tabular}{|c|c|c|c|c|c|}
\hline \multicolumn{6}{|c|}{ Proton chemical shift ${ }^{\mathrm{a}}$ (assignment) $^{\mathrm{b}}$} \\
\hline \multicolumn{2}{|c|}{ Ligand } & \multicolumn{2}{|c|}{ Zn binary complex } & \multicolumn{2}{|c|}{ Zn ternary complex } \\
\hline 7.47 & (d, 1H, H-1 Dhba) & 7.12 & $(\mathrm{~s}, 1 \mathrm{H}, \mathrm{H}-1)$ & $7.12-7.03$ & (m, 1H, H-1 Dhba) \\
\hline 7.16 & (d, 1H, H-2 Dhba) & 6.82 & $(\mathrm{~s}, 1 \mathrm{H}, \mathrm{H}-2)$ & 6.78 & (br, $1 \mathrm{H}, \mathrm{H}-2 \mathrm{Dhba})$ \\
\hline \multirow[t]{2}{*}{6.88} & $(\mathrm{t}, 1 \mathrm{H}, \mathrm{H}-3 \mathrm{Dhba})$ & 6.61 & $(\mathrm{~s}, 1 \mathrm{H}, \mathrm{H}-3)$ & $6.69-6.59$ & (m, 1H, H-3 Dhba) \\
\hline & & 3.69 & $\left(\mathrm{q}, 2 \mathrm{H}, \mathrm{CH}_{2}\right)$ & 4.53 & (q, 1H, CH Nac) \\
\hline 4.66 & $(\mathrm{q}, 1 \mathrm{H}, \mathrm{CH} \mathrm{Nac})$ & 1.22 & $\left(\mathrm{t}, 3 \mathrm{H}, \mathrm{CH}_{3}\right)$ & 3.69 & (q, $2 \mathrm{H}, \mathrm{CH}_{2}$ ethanol) \\
\hline 3.02 & (sep, $2 \mathrm{H}, \mathrm{CH}_{2} \mathrm{Nac}$ ) & & & $3.02-2.99$ & (dd, $2 \mathrm{H}, \mathrm{CH}_{2} \mathrm{Nac}$ ) \\
\hline \multirow[t]{2}{*}{2.11} & $\left(\mathrm{~s}, 3 \mathrm{H}, \mathrm{CH}_{3} \mathrm{Nac}\right)$ & & & 1.60 & $\left(\mathrm{~s}, 3 \mathrm{H}, \mathrm{CH}_{3} \mathrm{Nac}\right)$ \\
\hline & & & & 1.22 & (t, $3 \mathrm{H}, \mathrm{CH}_{3}$ ethanol) \\
\hline
\end{tabular}

a Proton chemical shift $(\delta)$ in ppm unit.

b Signal assignment in parenthesis represents the splitting pattern, number of proton, proton location in the compound geometry and splitting distance. Splitting pattern abbreviations: $\mathrm{s}=$ singlet, $\mathrm{d}=$ doublet, $\mathrm{t}=$ triplet, $\mathrm{q}=$ quartet, $\mathrm{sep}=$ septet, $\mathrm{dd}=$ doublet of doublets, $\mathrm{br}=$ broad, $\mathrm{m}=$ multiplet (complex pattern).

Table 4

Equilibrium constants at various temperatures and $I$ of $0.15 \mathrm{~mol} / \mathrm{l} \mathrm{NaCl}{ }^{\mathrm{a}}$.

\begin{tabular}{|c|c|c|c|c|c|c|c|c|}
\hline \multirow[t]{3}{*}{ Parameters } & \multicolumn{8}{|c|}{ Equilibrium constants at different temperature } \\
\hline & \multicolumn{2}{|l|}{$25^{\circ} \mathrm{C}$} & \multicolumn{2}{|l|}{$37^{\circ} \mathrm{C}^{\mathrm{b}}$} & \multicolumn{2}{|l|}{$45^{\circ} \mathrm{C}$} & \multicolumn{2}{|l|}{$55^{\circ} \mathrm{C}$} \\
\hline & Dhba & Nac & Dhba & Nac & Dhba & $\mathrm{Nac}$ & Dhba & Nac \\
\hline \multicolumn{9}{|c|}{ Dissociation constant } \\
\hline $\mathrm{p} K_{\mathrm{a} 1}$ & $2.68(2)$ & $3.17(3)$ & $2.63(4)$ & $3.18(2)$ & $2.60(3)$ & $3.12(2)$ & $2.54(1)$ & $3.12(1)$ \\
\hline $\mathrm{p} K_{\mathrm{a} 2}$ & $10.11(2)$ & $9.60(2)$ & $9.98(2)$ & $9.48(5)$ & $9.84(4)$ & $9.42(2)$ & $9.81(4)$ & $9.33(2)$ \\
\hline $\mathrm{p} K_{\mathrm{a} 3}$ & $\mathrm{nd}^{\mathrm{c}}$ & - & $13.00(2)$ & - & $12.72(1)$ & - & $12.60(2)$ & - \\
\hline$\sigma^{\mathrm{d}}$ & 1.13 & 1.06 & 1.02 & 1.02 & 1.05 & 1.26 & 1.23 & 1.09 \\
\hline \multicolumn{9}{|c|}{ Binary-stability constant } \\
\hline $\log _{10} \beta_{1}$ & $10.55(3)$ & $6.53(7)$ & $10.48(4)$ & $6.23(8)$ & $10.25(2)$ & $6.19(2)$ & $10.02(5)$ & $6.05(5)$ \\
\hline $\log _{10} \beta_{2}$ & $16.53(4)$ & $12.11(2)$ & $16.52(9)$ & $11.97(8)$ & $16.51(7)$ & $11.98(4)$ & $16.11(3)$ & $11.91(4)$ \\
\hline$\sigma^{\mathrm{d}}$ & 1.08 & 1.34 & 1.48 & 1.41 & 1.40 & 1.21 & 1.11 & 1.19 \\
\hline \multicolumn{9}{|c|}{ Ternary-stability constant } \\
\hline $\log _{10} \beta_{\mathrm{T}}$ & $16.59(8)$ & & $16.38(7)$ & & $16.02(5)$ & & $15.51(6)$ & \\
\hline$\sigma^{\mathrm{d}}$ & 1.56 & & 1.55 & & 1.61 & & 1.69 & \\
\hline$\Delta \log _{10} K$ & -0.49 & & -0.33 & & -0.42 & & -0.56 & \\
\hline $\log _{10} X$ & 4.54 & & 4.27 & & 3.55 & & 3.00 & \\
\hline
\end{tabular}

a Standard deviations in parentheses at last decimal place represent the standard uncertainties of temperature $u(T)=0.1^{\circ} \mathrm{C}$.

b Values cited from Refs. [11] and [15], potentiometry method at $I=0.15 \mathrm{~mol} / \mathrm{l} \mathrm{NaCl}$.

c Not defined.

d Sigma $(\sigma)$, the goodness of fitting in a system with expectation value of 1.00 .

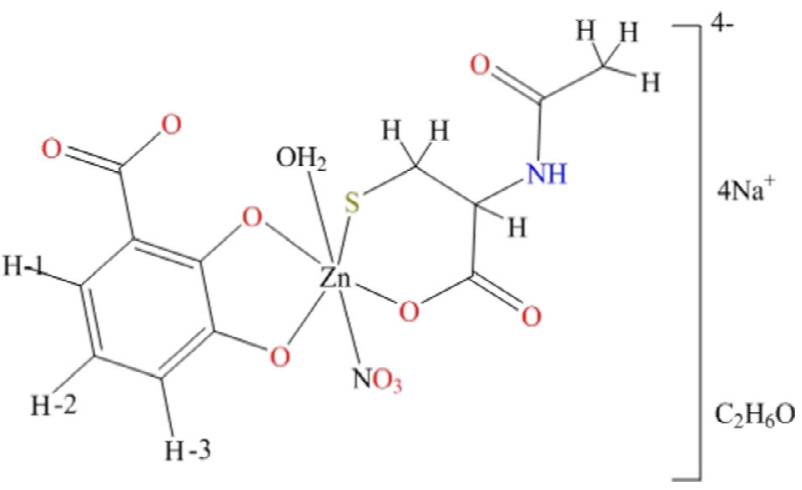

Fig. 5. Proposed structure of zinc ternary complex.

\subsubsection{Effect of temperature on thermodynamic parameters}

The dissociation constant $\left(\mathrm{p} K_{\mathrm{a}}\right)$ of Dhba and Nac as well as the stability constant $\left(\log _{10} \beta\right)$ of their binary and ternary complexes with $\mathrm{Zn}^{2+}$ in aqueous solution with $I=0.15 \mathrm{~mol} / \mathrm{l} \mathrm{NaCl}$ were determined at different temperatures $\left(25^{\circ} \mathrm{C}, 37^{\circ} \mathrm{C}, 45^{\circ} \mathrm{C}\right.$ and $55^{\circ} \mathrm{C}$ ) and the results are presented in Table 4. Particularly for $\mathrm{p} K_{\mathrm{a} 3}$ of Dhba at $25^{\circ} \mathrm{C}$, a big error occurred during refinement thus resulting in undefined value. The error may be caused by the decrease of the acidity of the ligand Dhba at low temperature resulting in delay in dissociation. The change of acidity is well demonstrated in Table 4 since $\mathrm{p} K_{\mathrm{a}}$ value decreased as the temperature was increased. In order to observe the capability of the ligand in preventing the formation of metal hydrolytic species, the hydrolysis constants were included in the determination of $\log _{10} \beta$. No metal hydrolytic species were observed in the systems, indicating that the ligands were capable in preventing their formation (Fig. S1). The $\log _{10} \beta$ of binary and ternary complexes also decrease with increasing temperature indicating that complex is more likely to disassociate at higher temperature.

Additional parameters $\Delta \log _{10} K$ and $\log _{10} X$ were determined with respect to the ternary species, where their values are calculated as:

$$
\Delta \log _{10} K=\log _{10} \beta_{\mathrm{Zn}(\mathrm{Dhba})(\mathrm{Nac})}-\left[\log _{10} \beta_{\mathrm{Zn}(\mathrm{Dhba})}+\log _{10} \beta_{\mathrm{Zn}(\mathrm{Nac})}\right]
$$

$\log _{10} X=2 \log _{10} \beta_{\mathrm{Zn}(\mathrm{Dhba})(\mathrm{Nac})}-\left[\log _{10} \beta_{\mathrm{Zn}(\mathrm{Dhba}) 2}+\log _{10} \beta_{\mathrm{Zn}(\mathrm{Nac}) 2}\right]$

Less negative $\Delta \log _{10} K$ indicates the formation of ternary species is more favorable than that of binary species [6,21]. At all temperatures, the complexes exhibit negative $\Delta \log _{10} K$ value 
Table 5

Thermodynamics properties of Dhba, Nac, binary and ternary complexes of Zn.

\begin{tabular}{|c|c|c|c|c|c|c|c|c|c|}
\hline \multirow[t]{2}{*}{ Species } & \multicolumn{4}{|c|}{$-\Delta G(\mathrm{~kJ} / \mathrm{mol})$} & \multirow[t]{2}{*}{$-\Delta H(\mathrm{~kJ} / \mathrm{mol})$} & \multicolumn{4}{|c|}{$\Delta S(\mathrm{~J} / \mathrm{K} \cdot \mathrm{mol})$} \\
\hline & $25^{\circ} \mathrm{C}$ & $37^{\circ} \mathrm{C}$ & $45^{\circ} \mathrm{C}$ & $55^{\circ} \mathrm{C}$ & & $25^{\circ} \mathrm{C}$ & $37^{\circ} \mathrm{C}$ & $45^{\circ} \mathrm{C}$ & $55^{\circ} \mathrm{C}$ \\
\hline $\mathrm{H}_{3}$ Dhba & 15.30 & 15.68 & 15.84 & 15.96 & 8.49 & 22.85 & 23.19 & 23.11 & 22.78 \\
\hline $\mathrm{H}_{2}$ Dhba & 57.72 & 59.27 & 59.95 & 61.64 & 19.45 & 128.35 & 128.39 & 127.29 & 128.57 \\
\hline HDhba & - & 77.20 & 77.49 & 79.17 & 41.80 & - & 114.14 & 112.17 & 113.88 \\
\hline $\mathrm{H}_{2} \mathrm{NaC}$ & 18.10 & 18.89 & 19.01 & 19.60 & 11.24 & 22.99 & 24.64 & 22.68 & 23.38 \\
\hline HNac & 54.81 & 56.30 & 57.39 & 58.62 & 16.33 & 129.07 & 128.89 & 129.06 & 128.90 \\
\hline Zn(Dhba) & 60.23 & 62.24 & 62.44 & 62.96 & 33.04 & 91.19 & 94.14 & 92.41 & 91.18 \\
\hline $\mathrm{Zn}(\mathrm{Dhba})_{2}$ & 94.37 & 98.11 & 100.58 & 101.23 & 22.77 & 240.15 & 242.91 & 244.57 & 239.09 \\
\hline $\mathrm{Zn}(\mathrm{Nac})$ & 37.28 & 37.00 & 37.71 & 38.02 & 28.36 & 29.93 & 27.86 & 29.40 & 29.43 \\
\hline $\mathrm{Zn}(\mathrm{Nac})_{2}$ & 69.14 & 71.09 & 72.98 & 74.84 & 11.43 & 193.56 & 192.37 & 193.48 & 193.24 \\
\hline $\mathrm{Zn}(\mathrm{Dhba})(\mathrm{Nac})$ & 94.71 & 97.28 & 97.59 & 97.46 & 65.78 & 97.04 & 101.56 & 100.00 & 97.64 \\
\hline
\end{tabular}

indicating that the formation of ternary complex is less preferred than binary complex. Such phenomenon probably occurred because of electrostatic effect between the ligands thus lowering the stability of the complex. Meanwhile, for $\log _{10} X$ parameter, the value higher than statistical value $(+0.6$ for all geometries) indicates remarkable stability of ternary complex. All of the ternary complexes exhibit positive $\log _{10} X$ greater than the statistical value. This point out that the secondary ligand (Dhba) prefers to attach at the binary complex $\mathrm{Zn}(\mathrm{Nac})$ rather than attach to metal ion. Nac is designated as the primary ligand and Dhba as the secondary ligand since the formation of Nac binary complexes took place at lower $\mathrm{pH}$ than that of Dhba binary complexes. The $\log _{10} X$ decreases with increasing temperature, indicating that ternary complex is less stable at higher temperature. This trend is supported by the $\log _{10} \beta$ values which also decreased with increasing temperature.

Thermodynamic properties such as $\Delta G$ (Gibbs free energy), $\Delta H$ (enthalpy) and $\Delta S$ (entropy) provides significant information related to the complex. $\Delta G$ can be calculated as:

$\Delta G=-2.303 R T \log _{10} \beta$

$\Delta H$ can be determined as the slope of the Van't Hoff plot which is defined as:

$\log _{10} \beta=\left(\frac{-\Delta H}{2.303 R}\right) 1 / T+\left(\frac{-\Delta S}{2.303 R}\right)$

Thermodynamic properties of Dhba, Nac as well as the Zn binary and ternary complexes are given in Table 5.

Negative values of $\Delta G$ and $\Delta H$ in the dissociation of the ligands and chelation of binary and ternary $\mathrm{Zn}$ complexes indicate that the reactions are spontaneous and exothermic, so that lower temperature is more favorable for complex synthesis. All $\Delta S$ values are positive indicating that complex formation is favorable.

\section{Conclusion}

Binary and ternary complexes of M/Dhba/Nac were synthesized. FTIR spectra and UV-vis spectra indicate that all complexes have similar structure. The complexes did not increase the scavenging activity of Dhba against DPPH. However in the antimicrobial evaluations against $S$. aureus and $E$. coli, the complexes were found to be more effective than that of Dhba which is caused by the enhancement of hydrophobicity of the complexes. The binary and ternary complexes of $\mathrm{Zn}$ gave the best enhancement in antimicrobial activity of Dhba and were characterized further. The binary complex was found to bind metal ion through ortho and meta -0 group, which has the molecular structure $\mathrm{C}_{9} \mathrm{H}_{11} \mathrm{NNa}_{2} \mathrm{O}_{9} \mathrm{Zn}$. The ternary complex was found to bind metal ion through ortho and meta -O group of Dhba, and $-\mathrm{COO}$ and $-\mathrm{S}$ of Nac, which has the molecular structure $\mathrm{C}_{14} \mathrm{H}_{18} \mathrm{~N}_{2} \mathrm{Na}_{4} \mathrm{O}_{12} \mathrm{SZn}$. The formation of binary and ternary complex was found to be spontaneous and exothermic.

\section{Acknowledgments}

This study was supported by a project (MOST 103-2221-E-011148) from the Ministry of Science and Technology, Taiwan. The authors thank Shang-Ming Tseng of Instrumentation Center, National Taiwan University for magnetic (MPMS7 Quantum Design SQUID Magnetometer) experiments.

\section{Supplementary materials}

Supplementary material associated with this article can be found, in the online version, at doi:10.1016/j.jtice.2016.08.003.

\section{References}

[1] Penesyan A, Gillings M, Paulsen IT. Antibiotic discovery: combatting bacterial resistance in cells and in biofilm communities. Molecules 2015;20:5286-98.

[2] Williams LB, Haydel SE. Evaluation of the medicinal use of clay minerals as antibacterial agents. Int Geol Rev 2010;52:745-70.

[3] Abbehausen C, Heinrich TA, Abrao EP, Costa-Neto CP, Lustri WR, Formiga ALB, et al. Chemical, spectroscopic characterization, DFT studies and initial pharmacological assays of a silver(I) complex with $\mathrm{N}$-acetyl- ${ }_{-}-$cysteine. Polyhedron 2011;30:579-83.

[4] Bruckner C, Caulder DL, Raymond KN. Preparation and structural characterization of nickel(II) catecholates. Inorg Chem 1998;37:6759-64.

[5] Bukhari SB, Memon S, Tahir MM, Bhanger MI. Synthesis, characterization and antioxidant activity copper-quercetin complex. Spectrochim Acta Mol Biomol Spectros 2009;71:1901-6.

[6] Dharmaraja J, Esakkidurai T, Subbaraj P, Shobana S. Mixed ligand complex formation of 2-aminobenzamide with $\mathrm{Cu}(\mathrm{II})$ in the presence of some amino acids: synthesis, structural, biological, pH-metric, spectrophotometric and thermodynamic studies. Spectrochim Acta Mol Biomol Spectros 2013;114:607-21.

[7] George S, Benny PJ, Kuriakose S, George C, Gopalakrishnan S. Antiprotozoal activity of 2, 3-dihydroxybenzoic acid isolated from the fruit extracts of Flacourtia inermis Robx. Asian J Pharm Clin Res 2011;3:237-41.

[8] Juurlink BHJ, Azouz HJ, Aldalati AMZ, Al Tinawi BMH, Ganguly P. Hydroxybenzoic acid isomers and the cardiovascular system. Nutr J 2014;13:63.

[9] Harada H. An investigation of the stability constant of the 2, 3-dihydroxybenzoic acid complex with copper(II). Bull Chem Soc Jpn 1971;44:3459-60.

[10] Kiss T, Kozlowski H, Micera G, Erre LS. Copper(II) complexes of 2, 3-dihydroxybenzoic acid. J Coord Chem 1989;20:49-56.

[11] Santoso SP, Angkawijaya AE, Ismadji S, Ayucitra A, Soetaredjo FE, Lan TNP, et al. Complex formation study of binary and ternary complexes including 2 3-dihydroxybenzoic acid, N-acetylcysteine and divalent metal ions. J Sol Chem 2016:1-16.

[12] Dean O, Giorlando F, Berk M. N-acetylcysteine in psychiatry: current therapeutic evidence and potential mechanisms of action. J Phsychiatry Neurosci 2011;36:78-86

[13] Samuni Y, Goldstein S, Dean OM, Berk M. The chemistry and biological activities of N-acetylcysteine. Biochim Biophys Acta 2013;1830:4117-29.

[14] Guzeloglu S, Yalcin G, Pekin M. The determination of stability constant of $\mathrm{N}$-acetyl-L-cysteine chrome, nickel, cobalt and iron complexes by potentiometric method. J Organomet Chem 1998;568:143-7.

[15] Santoso SP, Chandra IK, Soetaredjo FE, Angkawijaya AE, Ju YH. Equilibrium studies of complexes between N-acetylcysteine and divalent metal ions in aqueous solutions. J Chem Eng Data 2014;59:1661-6.

[16] Alam MN, Bristi NJ, Rafiquzzaman M. Review on in vivo and in vitro methods evaluation of antioxidant activity. Saudi Pharm J 2013;21:143-52.

[17] Wiegand I, Hilpert K, Hancock REW. Agar and broth dilution methods to determine the minimal inhibitory concentration (MIC) of antimicrobial substances. Nature Protocols 2008;3:163-75. 
[18] Gans P, Sabatini A, Vacca A. Determination of equilibrium constants from spectrophometric data obtained from solutions of known pH: the program pHab. Talanta 1996;43:1739-53.

[19] Nakamoto K. Infrared and Raman spectra of inorganic and coordination compounds. New York: Wiley; 1986.

[20] Shebl M, Ibrahim MA, Khalil SME, Stefan SL, Habib H. Binary and ternary copper(II) complexes of a tridentate ONS ligand derived from 2-aminochromone-3 carboxaldehyde and thiosemicarbazide: synthesis, spectral studies and antimicrobial activity. Spectrochim Acta Mol Biomol Spectros 2013;115:399-408.

[21] Chandra IK, Angkawijaya AE, Santoso SP, Ismadji S, Soetaredjo FE, Ju YH. Solution equilibria studies of complexes of divalent metal ions with 2-aminophenol and 3,4-dihydroxybenzoic acid. Polyhedron 2015;88:29-39.

[22] Abdallah SM, Zayed MA, Mohamed GG. Synthesis and spectroscopic characterization of new tetradentate Schiff base and its coordination compounds of NOON donor atoms and their antibacterial and antifungal activity. Arab J Chem 2010;3:103-13
[23] Jing P, Zhao SJ, Jian WJ, Qian BJ, Dong Y, Pang J. Quantitative studies on structure-DPPH* scavenging activity relationship of food phenolic acids. Molecules 2012;17:12910-24.

[24] Kitaoka N, Liu G, Masuoka N, Yamashita K, Manabe M, Kodama H. Effect of sulfur amino acids on stimulus-induced superoxide generation and translocation of p47phox and p67phox to cell membrane in human neutrophils and the scavenging of free radical. Clin Chim Acta 2005;353:109-16.

[25] Ozcelik D, Uzun H, Naziroglu M. N-Acetylcysteine attenuates copper overload-induced oxidative injury in brain of rat. Biol Trace Elem Res 2012;147:292-8.

[26] Atmaca S, Gul K, Cicek P. The effect of zinc on microbial growth. Tr J Med Sci 1998;28:595-7.

[27] Popova TP, Alexandrova RI, Tudose R, Mosoarca EM, Costisor O. Antimicrobial activity in vitro of four nickel complexes. Bulg J Agric Sci 2012;18:446-50.

[28] Silhavy TJ, Kahne D, Walker S. The bacterial cell envelope. Cold Spring Harb Perspect Biol 2010;2:1-16. 